\title{
PELATIHAN PENGEMBANGAN PENGUASAAN APLIKASI MEDIA SOSIAL UNTUK MENINGKATKAN PENDAPATAN KELUARGA
}

\author{
${ }^{1}$ Erlita Kurniawaty, ${ }^{2}$ Fauziah Septiani, ${ }^{3}$ Samsul Anwar \\ ${ }^{1,2}$ Dosen Fakultas Ekonomi Universitas Pamulang \\ ${ }^{3}$ Dosen Fakultas Keguruan Dan Ilmu Pendidikan Universitas Pamulang \\ Email : ${ }^{1}$ wshizakuu@gmail.com
}

\begin{abstract}
ABSTRAK
Dalam ilmu ekonomi, bisnis adalah suatu organisasi yang menjual barang atau jasa kepada konsumen atau bisnis lainnya, untuk mendapatkan laba. Secara historis kata bisnis dari bahasa Inggris business, dari kata dasar busy yang berarti "sibuk" dalam konteks individu, komunitas, ataupun masyarakat dalam artian, sibuk mengerjakan aktivitas dan pekerjaan yang mendatangkan keuntungan. Tujuan kegiatan ini adalah memberikan pelatihan pengembangan penguasaan aplikasi media sosial untuk meningkatkan pendapatan keluarga, Hasil dari kegiatan ini adalah para peserta diajarkan bagaimana menguasai aplikasi media sosial untuk meningkatkan pendapatan keluarga, dengan cara mulai berwirausaha dan berbisnis dengan menggunakan aplikasi media sosial yang dapat menekan modal dalam pemasaran dan menekan biaya promosi. Kegiatan dilaksanakan di Kecamatan Ciputat, Kota Tangerang Selatan.
\end{abstract}

\section{Kata Kunci : Aplikasi Media Sosial, Pendapatan Keluarga}

\section{PENDAHULUAN}

Dalam ekonomi kapitalis, di mana kebanyakan bisnis dimiliki oleh pihak swasta, bisnis dibentuk untuk mendapatkan profit dan meningkatkan kemakmuran para pemiliknya. Pemilik dan operator dari sebuah bisnis mendapatkan imbalan sesuai dengan waktu, usaha, atau kapital yang mereka berikan. Namun tidak semua bisnis mengejar keuntungan seperti ini, misalnya bisnis koperatif yang bertujuan meningkatkan kesejahteraan semua anggotanya atau institusi pemerintah yang bertujuan meningkatkan kesejahteraan rakyat. Model bisnis seperti ini kontras dengan sistem sosialistik, di mana bisnis besar kebanyakan dimiliki oleh pemerintah, masyarakat umum, atau serikat pekerja.

Secara etimologi, bisnis berarti keadaan di mana seseorang atau sekelompok orang sibuk melakukan pekerjaan yang menghasilkan keuntungan. Kata "bisnis" sendiri memiliki tiga penggunaan, tergantung skupnya - penggunaan singular kata bisnis dapat merujuk pada badan usaha, yaitu kesatuan yuridis (hukum), teknis, dan ekonomis yang bertujuan mencari laba atau keuntungan. Penggunaan yang lebih luas dapat merujuk pada sektor pasar tertentu, misalnya "bisnis pertelevisian." Penggunaan yang paling luas merujuk pada seluruh aktivitas yang dilakukan oleh 
komunitas penyedia barang dan jasa. Namun definisi "bisnis" yang tepat masih menjadi bahan perdebatan hingga saat ini.

\section{METODE PELAKSANAAN KEGIATAN}

Konten adalah sarana bagi anda, pemilk bisnis, untuk menuangkan kreativitas dan memikat hati para pengunjung. Bukan hanya bisnis online berbasis informasi yang membutuhkan konten, bahkan e-commerce sekalipun juga membutuhkan konten. Makanya beberapa toko online besar sekalipun seperti Tokopedia juga punya blog.

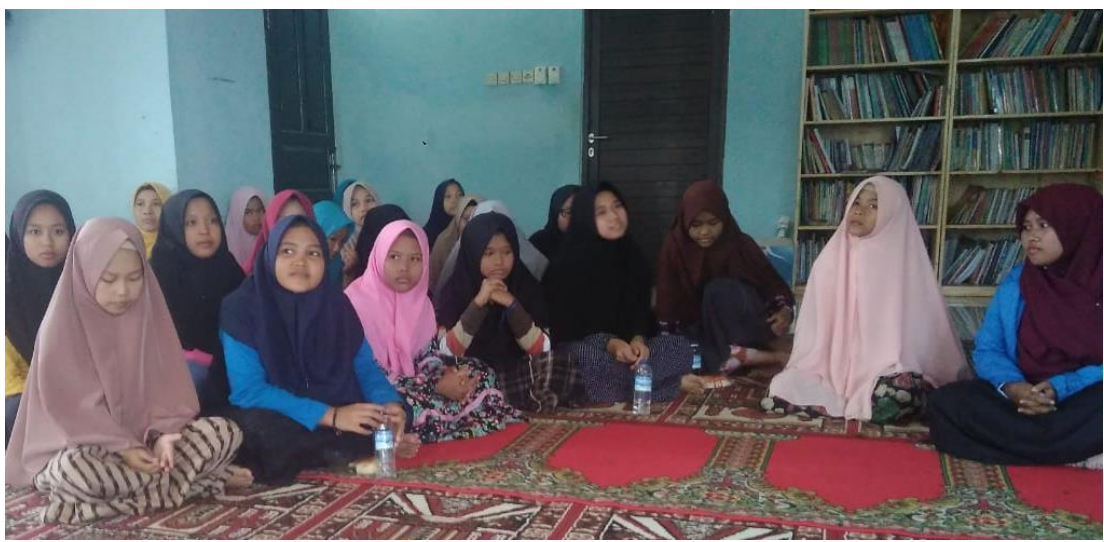

\section{Jenis-jenis konten}

Artikel adalah konten, tapi konten bukan hanya artikel. Artikel hanya salah satu jenis konten, masih ada lagi jenis konten yang lainnya. Berikut ini jenis-jenis konten selain artikel.

a) Video

Video adalah konten yang populer terutama karena mudah dinikmati. Video yang menarik seringkali menjadi viral di social media. Bagi anda yang menjual produk, video bisa digunakan untuk menjelaskan produk anda di landing page.

b) e-Book

E-book merupakan konten yang lebih mendetail daripada artikel biasa. Isi dari e-book umumnya lebih berharga dan lebih mendetail daripada sekedar artikel. E-book juga bisa digunakan sebagai pancingan agar visitor mau mendaftar di email list anda.

c) Infografis

Infografis biasanya berupa gambar yang berisikan representasi visual dari data. Infografis berisi angka-angka yang dirangkum dalam tabel, grafik,dan diagram yang didapatkan dari hasil penelitian. Karena berupa gambar, infografis lebih cepat menyebar di internet ketimbang artikel dan e-book. 


\section{d) Kursus online}

Bisa berupa artikel atau vide. Bedanya, kursus online berupa seri yang lebih dari satu chapter atau bab. Panduan bisnis online yang sedang anda baca ini juga bisa dikategorikan sebagai kursus online.

e) Audio (Podcast)

Podcast semakin lama semakin populer karena mudah diakses dan bisa didengarkan sambil melakukan aktivitas lain.

\section{Panduan membuat konten yang baik}

Membuat konten tentunya tidak asal-asalan, karena konten yang berkualitas rendah justru berdampak negatif untuk bisnis anda. Ada beberapa indikasi konten yang baik.

a) Relevan dengan tujuan akhir bisnis anda. Misalkan anda menjual produk berupa e-book teknik bermain gitar, maka konten yang anda buat harusnya mengenai bermain gitar. Dalam konten yang anda buat juga sebaiknya sesekali mempromosikan produk anda.

b) Menyelesaikan masalah. Orang-orang mencari konten di internet karena mereka punya rasa ingin tahu atau punya masalah tertentu. Konten yang baik dapat menyelesaikan masalah pembaca atau menjawab rasa ingin tahu mereka.

c) Memiliki format yang mudah untuk disimak. Jangan sampai proses membaca konten banyak diganggu oleh yang tidak berhubungan seperti desain atau formatting lainnya.

d) Punya referensi yang akurat. Konten yang baik punya sumber referensi yang terpercaya atau sudah terbukti melalui penelitian dan sejenisnya.

e) Dibuat dengan usaha maksimal. Konten harus padat dengan informasi yang berguna, untuk membuat informasi yang berguna ini tentunya butuh usaha maksimal yang tidak setengah-setengah.

f) Dibuat oleh ahlinya. Kalau anda sama sekali bukan tipe seorang penulis atau tidak suka menulis, serahkan saja tugas content marketing kepada ahlinya daripada konten yang dihasilkan justru tidak berkualitas. Tapi jangan khawatir kalau anda memang ingin membuat konten sendiri, practice makes perfect.

g) Punya judul yang mengundang rasa penasaran. Seberapa pun bagusnya isi kontennya, yang pertama dilihat adalah judul konten. Maka dari itu judul konten juga sangat penting.

\section{HASIL DAN PEMBAHASAN}

Hasil dari kegiatan ini adalah para peserta diajarkan bagaimana menguasai aplikasi media sosial untuk meningkatkan pendapatan keluarga, dengan cara mulai berwirausaha dan berbisnis dengan menggunakan aplikasi media sosial yang dapat menekan modal dalam pemasaran dan menekan biaya promosi. 


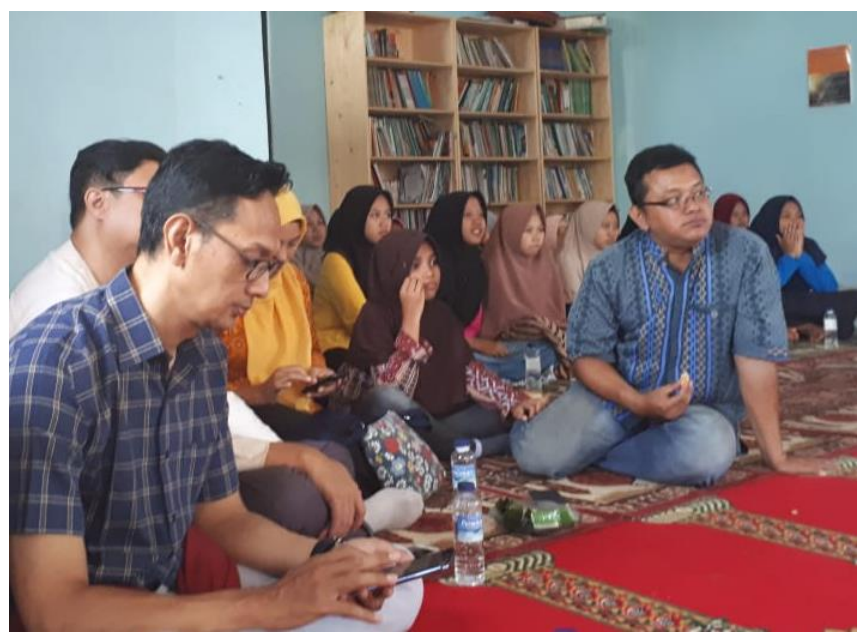

\section{KESIMPULAN DAN SARAN}

Dengan ada nya kegiatan ini menjadikan para peserta dapat membuat konten bisnis online di media sosial. Selama kegiatan berlangsung peserta memberikan tanggapan yang baik, hal ini dapat dilihat dari dukungan mereka dalam setiap kegiatan yang di adakan, sehingga dapat membantu para peserta mempersiapkan masa depannya.

\section{DAFTAR PUSTAKA}

https://id.wikipedia.org/wiki/Media_sosial

https://academy.getcraft.com/id/memahami-jenis-jenis-media-sosial 